\title{
THE NON-LINEAR RELATIONSHIP BETWEEN VOLATILITY AND SOVEREIGN CREDIT RISK: EVIDENCE FROM EMERGING COUNTRIES
}

\author{
DOI: 10.17261/Pressacademia.2020.1368 \\ PAP- V.12-2020(32)-p.106-107
}

Fatih Yigit $^{1}$, Fuzuli Aliyev ${ }^{2}$

${ }^{1}$ Istanbul Medeniyet University, The Department of Management, Istanbul, Turkey. fatih.yigit@medeniyet.edu.tr, ORCID: 0000-0002-1988-7962

${ }^{2}$ Baku Engineering University, The Department of Finance, Baku, Azerbaijan.

faliyev@beu.edu.az, ORCID: 0000-0001-5851-1581

\section{To cite this document}

Yigit, F., Aliyev, F., (2020). The non-linear relationship between volatility and sovereign credit risk: evidence from emerging countries. PressAcademia Procedia (PAP), V.12, p.106-107.

Permanent link to this document: http://doi.org/10.17261/Pressacademia.2020.1368

Copyright: Published by PressAcademia and limited licensed re-use rights only.

\section{ABSTRACT}

Purpose- This study investigates the nexus between the volatility index of VIX, and sovereign credit risk of CDS spread, in emerging markets, namely China, Russia, Brazil, Turkey, and Mexico. The emerging markets are in the center of investors' interest due to high return opportunities. The research aims to find out the relationship between the VIX index and the CDS spread of the abovementioned countries in the nonlinear level.

Methodology- The relationship between volatility and sovereign credit risk has been studied many times via linear models. However, financial series exhibit asymmetric dynamics, as volatility clustering, excess kurtosis, and others. Thus we use nonlinear autoregressive distributed lags (NARDL) analysis to capture nonlinear relations between the volatility and the sovereign credit risks of these countries by using daily data from 04.01.2010 to 29.11.2019. The linear ARDL model, that assumes symmetric dynamics of the variables, is not able to model the potential nonlinearity between CDS spreads and volatility movements. That is why we employ a nonlinear approach at this paper.

Findings- We apply the Wald test to check the cointegration between CDS and VIX, and find that all time series cointegrated and asymmetric dynamics. The bounds test of the NARDL model confirms the cointegration between VIX and CDS spreads of the countries under study. The analysis of estimated NARDL parameters shows that negative shocks of the volatility index have a long-lasting impact on CDS spreads. Chinese CDS spread are more sensitive to VIX index changes in the short run. The effect of a decrease in volatility on Russian CDS spread is higher than the effect of an increase. Turkish and Brazilian CDS spreads are more reactive to increase in the VIX, whereas Mexican CDS is less sensitive. Analyse outputs show there are asymmetric relations evident both in short-run and long-run periods.

Conclusion- Findins show that the impact of the shocks is asymmetric, and the impact of negative shocks on CDS spreads are higher than positive shocks of the same magnitude. These findings allow investors to consider global indicators when taking a position on sovereign bonds of emerging markets. Thus watching the VIX index, they may buy or sell the government bonds of these countries and they must consider its asymmetric impact.

Keywords: Volatility; Credit Default Swap; Asymmetry; NARDL

JEL Codes: C22; F65; G15

\section{REFERENCES}

Agliardi, E., Agliardi, R., Pinar, M., Stengos, T., \& Topaloglou, N. (2012). A new country risk index for emerging markets: A stochastic dominance approach. Journal of Empirical Finance, 19(5), 741-761.

Aliyev, F. (2019). Testing market efficiency with nonlinear methods: Evidence from Borsa Istanbul. International Journal of Financial Studies, $7(2), 27$.

Alqaralleh, Huthaifa (2020). Stock return-inflation nexus; revisited evidence based on nonlinear ARDL Journal of Applied Economics, 23(1), 66-74.

Ballester, L., \& González-Urteaga, A. (2017). How credit ratings affect sovereign credit risk: Cross-border evidence in Latin American emerging markets. Emerging Markets Review, 30, 200-214. 
Borri, N., \& Verdelhan, A. (2011). Sovereign risk premia. Paper presented at the AFA 2010 Atlanta Meetings Paper.

Chan, K. C., Fung, H.-G., \& Zhang, G. (2009). On the relationship between asian sovereign credit default swap markets and equity markets. Journal of Asian Business Studies, 4(1), 3-12.

Enders, W., \& Lee, J. (2012). The flexible Fourier form and Dickey-Fuller type unit root tests. Economics Letters, 117(1), $196-199$.

Eyssell, T., Fung, H.-G., \& Zhang, G. (2013). Determinants and price discovery of China sovereign credit default swaps. China Economic Review, 24, 1-15.

Figuerola-Ferretti, I., \& Paraskevopoulos, I. (2013). Pairing market risk and credit risk. Available at SSRN 1553863.

Jeanneret, A. (2015). The dynamics of sovereign credit risk. Journal of Financial and Quantitative Analysis, 50(5), 963-985.

Longstaff, F. A., Pan, J., Pedersen, L. H., \& Singleton, K. J. (2011). How sovereign is sovereign credit risk? American Economic Journal: Macroeconomics, 3(2), 75-103.

Maltritz, D., \& Molchanov, A. (2014). Country credit risk determinants with model uncertainty. International Review of Economics \& Finance, 29, 224-234.

Ricciardi, A. (2016). Exploiting the cointrgration between VIX and CDS in a credit market timing model. Unpublished Doctoral Dissertation.

Shin, Y., Yu, B., \& Greenwood-Nimmo, M. (2014). Modelling asymmetric cointegration and dynamic multipliers in a nonlinear ARDL framework. In R. C. Sickles \& W. C. Horrace (Eds.), Festschrift in Honor of Peter Schmidt (pp. 281-314). New York, NY: Springer. 